\title{
Profile Characteristics of Farm Women with Reference to Knowledge Groups in Maheshwarammandal of Rangareddy District, India
}

\author{
N. Sunitha ${ }^{1^{*}}$, T. Sarah Kamala ${ }^{2}$ and R. Neela Rani ${ }^{3}$ \\ ${ }^{1}$ Department of Home science extension and communication management, College of Home \\ Science, PJTSAU, Hyderabad, India \\ ${ }^{2}$ EXTN-AICRP (Home Science), PJTSAU, Hyderabad, India \\ ${ }^{3}$ Department of Home science extension and communication management, College of Home
}

Science, PJTSAU, Hyderabad, India

*Corresponding author:

\begin{abstract}
A B S T R A C T
Keywords

Farm women, Farming, Crops, Extension personnel, Organizational participation

Article Info

Accepted:

12 June 2019

Available Online:

10 July 2019

The present study was conducted in Maheswarammandal of Ranga Reddy district, Telangana. A total of 120 farm women who engaged in farming were selected through purposive random sampling technique. The results revealed that majority $(53.33 \%)$ of the farm women belonged to the age group of young age i.e., 18-35 years were married $(86.67 \%)$ and $31.67 \%$ had completed their high school education and farm women were having below 10 years of work experience $(38.33 \%)$. Majority $(45 \%)$ of the farm women were having farming as their family occupation by holding medium level land size (35\%) having their own lands (99\%) and belonged to small families $(84.17 \%$ ) with less than three members in the family. It was observed that main crops cultivated in the selected locale by the farm women were cotton $(87.50 \%)$, cereals $(79.17 \%)$, vegetables $(76.67 \%)$ and flowers $(66.67 \%)$. Less than cent per cent $(81.67 \%)$ of the farm women were participating regularly in self-help groups by contacting community coordinator $(68.33 \%)$ as their external personnel and received cent percent of source of information about farming from traditional knowledge and family members.
\end{abstract}

\section{Introduction}

In India, women were involved highly in farm activities as well as household activities which act as the obstacles for her to empower the farm activities. In performing different farm activities there are various farm tools and technologies which are not much known to the farm women. When there is no much knowledge about the new technologies in agriculture, the women faces problem in doing farm activities and have to depend on other external individual for support. The world is changing very fast pace were women require a platform to exchange their knowledge in every aspect of life seen i.e., society, agriculture, economy, livelihood etc. Information is essential for the development of knowledge in accordance to their livelihood and daily activities. 
Bansal and Joshi (2018) revealed that seventy per cent of respondents belonged to young age group and 80 per cent were married and had farming $(81 \%)$ as their main occupation. Nearly three fourth of the respondents (79$100 \%$ ) didn't have any participation in other organization viz. Mahilamandal, zila Panchayat and taluk Panchayat. Kumawat (2017) also reported that 47 per cent respondents belonged to age group of 31-45 years. Majority of the respondents were married (88\%) and illiterate (55\%). Majority of the respondents $(70 \%)$ belonged to the category of low socio-economic status. Dayya et al., (2016) reported 89 per cent of the respondents had no organizational membership whereas, 11 per cent respondents were member of formal organization (SHGs).Thus, it is very important to study the profile characteristics of farm women to associate them into knowledge groups to empower women in agriculture with available sources.

\section{Materials and Methods}

Exploratory research design was adopted for the present study. A total of 120 farm women who engaged in farming were selected randomly from 6 villages of Maheswarammandal of Rangareddy district. Interview schedule was used for data collection. Frequencies, percentages, mean and standard deviation were used for analyzing the data by using MS excel.

\section{Results and Discussion}

Profile characteristics of farm women was collected under the following heads like age, educational qualification, marital status, size of family, type of family, family occupation, farm women occupation, land holding, cultivable land, work experience, main crop in cultivation, source of information about farming, organizational participation and frequency of contact with extension personnel. The data was tabulated, presented and discussed below.

From the distribution of table, majority $(53.33 \%)$ of the farm women fall under the age group of young age i.e. 18-35 years followed by 38.33 per cent middle age i.e. 3650 whereas only few 8.33 per cent farm women are in the age group of above 50 years From this it is evident that in India, majority of the farm works are being done by women farmers only and majority of the farm women were in the age group of 18 years to 50 years who are actively involved in farming (Table $1)$.

It is clear from Table 2, maximum (31.67\%) of the farm women had completed their high school education, followed by college education by $1 / 4^{\text {th }}(24.17 \%)$ of the farm women while around small percentage of the farm women were having middle schooling $(17.50 \%)$ and $(13.33 \%)$ illiteracy education levels. Only 5.83 percent of the farm women had completed their graduation and above level of education.

From Figure 1, Highest $(86.67 \%)$ percentage of farm women were married while nearly twelve percent $(11.67 \%)$ of them were widows and only few (1.67\%) were unmarried.

From Table 3, the results revealed that utmost $(84.17 \%)$ of the farm women were belonged to small families with less than three members in the family, followed by medium families $(10.83 \%)$ with $4-5$ members in the family and only 5 percent of farm women were belonged to the large families viewing the lessening of joint and large families in now a day's societies.

From Figure 2, Greater part $(90 \%)$ of farm women belonged to the nuclear families. Only 12 percentages are from joint families. 
Table 4 depicts that majority $(45 \%)$ of the farm women were having farming as their family occupation followed by the farming along with business $(25.83 \%)$ and next mainly followed family occupation was farming along with service with 20.00 per cent while only farming with daily wage earnings was least $(9.17 \%)$ taken up family occupation by the farm women showing their active involvement in farming in one or other ways.
From the distribution of Table 5 results revealed that farming was most engaged occupation by the good number $(47.5 \%)$ of the farm women. Farming along with business was next followed occupation $(22.50 \%)$ of the farm women and almost equal percentage of the farm women were engaged in only farming along with service $(15.8 \%)$ and farming cum daily wage earner (14.2\%).

\begin{tabular}{|l|c|c|}
\hline \multicolumn{3}{|c|}{ Table.1 Distribution of farm women by age in years } \\
N=120
\end{tabular}

\begin{tabular}{|l|c|c|}
\hline \multicolumn{2}{|c|}{ Table.2 Distribution of farm women by educational qualification } & N=120 \\
\hline Category & $\begin{array}{c}\text { Frequency } \\
(\mathrm{N})\end{array}$ & $\begin{array}{c}\text { Percentage } \\
(\%)\end{array}$ \\
\hline Illiterate & 16 & 13.33 \\
\hline Primary School & 9 & 7.50 \\
\hline Middle School & 21 & 17.50 \\
\hline High School & 38 & 31.67 \\
\hline Intermediate & 29 & 24.17 \\
\hline Graduation \& Above & 7 & 5.83 \\
\hline Total & \multicolumn{3}{|c|}{$3.63 \pm 1.42$} \\
\hline Mean+S.D
\end{tabular}

\begin{tabular}{|l|c|c|}
\hline \multicolumn{2}{|c|}{ Table.3 Distribution of farm women by family size } & N=120 \\
\hline \multicolumn{1}{|c|}{ Category } & $\begin{array}{c}\text { Frequency } \\
(\mathrm{N})\end{array}$ & $\begin{array}{c}\text { Percentage } \\
(\%)\end{array}$ \\
\hline Small (less than 3 member) & 101 & 84.17 \\
\hline Medium (4-5 member) & 13 & 10.83 \\
\hline Large (7-9 member) & 6 & 5.00 \\
\hline Total & \multicolumn{3}{|c|}{$2.96 \pm 1.3$} \\
\hline Mean+S.D
\end{tabular}




\begin{tabular}{|l|c|c|}
\hline \multicolumn{3}{|c|}{ Table.4 Distribution of farm women by occupation of the family } \\
N=120
\end{tabular}

\begin{tabular}{|l|c|c|}
\hline \multicolumn{3}{|c|}{ Table.5 Distribution of farm women by occupation } \\
N=120 \\
\hline \multicolumn{1}{|c|}{ Category } & $\begin{array}{c}\text { Frequency } \\
\text { (N) }\end{array}$ & $\begin{array}{c}\text { Percentage } \\
(\%)\end{array}$ \\
\hline Farming & 57 & 47.50 \\
\hline Farming and service & 19 & 15.83 \\
\hline Farming and business & 27 & 22.50 \\
\hline Farming and daily wage earner & 17 & 14.17 \\
\hline Total & \multicolumn{2}{|c|}{120} \\
\hline
\end{tabular}

\begin{tabular}{|l|c|c|}
\hline \multicolumn{3}{|c|}{ Table.6 Distribution of farm women by land holding } \\
N=120
\end{tabular}

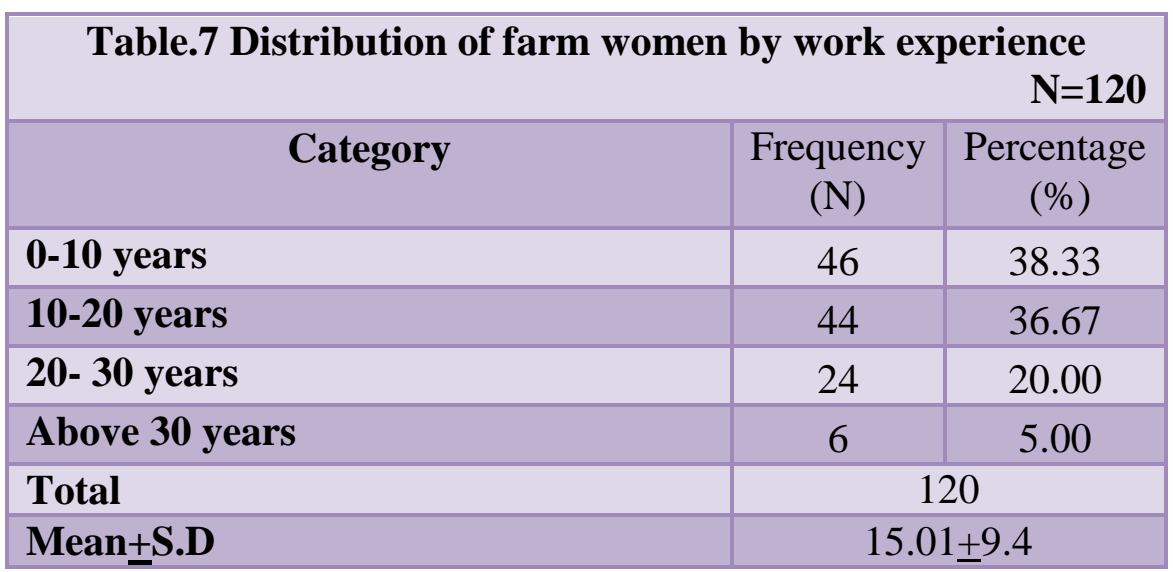




\begin{tabular}{|c|c|c|}
\hline \multicolumn{2}{|c|}{ Table. 8 Main crop in cultivation } & $\mathrm{N}=\mathbf{1 2 0}$ \\
\hline Crops & $\begin{array}{c}\text { Yes } \\
\mathrm{F}(\%)\end{array}$ & $\begin{array}{c}\text { No } \\
\text { F (\%) }\end{array}$ \\
\hline Cereals (paddy, maize) & $\begin{array}{c}95 \\
(79.17)\end{array}$ & $\begin{array}{c}25 \\
(20.83)\end{array}$ \\
\hline Pulses (red gram dhal) & $\begin{array}{c}67 \\
(55.83)\end{array}$ & $\begin{array}{c}53 \\
(44.17)\end{array}$ \\
\hline $\begin{array}{l}\text { Flowers } \\
\text { (Chrysanthemum, lily, } \\
\text { jasmine and rose) }\end{array}$ & $\begin{array}{c}80 \\
(66.67)\end{array}$ & $\begin{array}{c}40 \\
(33.33)\end{array}$ \\
\hline Vegetables (all types) & $\begin{array}{c}92 \\
(76.67)\end{array}$ & $\begin{array}{c}28 \\
(23.33)\end{array}$ \\
\hline Cotton & $\begin{array}{c}105 \\
(87.50)\end{array}$ & $\begin{array}{c}15 \\
(12.50)\end{array}$ \\
\hline
\end{tabular}

\begin{tabular}{|l|c|c|}
\hline \multicolumn{2}{|c|}{ Table.9 Source of information about farming } & N=120 \\
\hline Sources & $\begin{array}{c}\text { Yes } \\
\text { F (\%) }\end{array}$ & $\begin{array}{c}\text { No } \\
\text { F }(\%)\end{array}$ \\
\hline Traditional knowledge & 120 & -- \\
\hline News paper & $(100.00)$ & \\
\hline Krishi Vignan Kendras (KVKs) & 32 & 88 \\
& $(26.67)$ & $(73.33)$ \\
\hline Agricultural University & 12 & 108 \\
\hline Climate related agricultural & $30.00)$ & $(90.00)$ \\
\hline counseling & $(25.00)$ & 90 \\
\hline Agricultural Extension Officer & -- & $(75.00)$ \\
(AEO) & 720 \\
\hline Television (TV) & $(60.00)$ & $(100.00)$ \\
\hline Radio & 98 & 48 \\
& $(81.66)$ & $(18.33)$ \\
\hline Mobile phone & 35 & 85 \\
& $(29.17)$ & $(70.83)$ \\
\hline Family members & 54 & 66 \\
& $(45.00)$ & $(55.00)$ \\
\hline Neighbour's & 120 & -- \\
& $(100.00)$ & \\
\hline
\end{tabular}




\begin{tabular}{|l|c|c|c|}
\hline \multicolumn{2}{|c|}{ Table.10 Percent distribution of farm women according to organizational participation } \\
N=120
\end{tabular}

Table.11 Distribution of farm women according to frequency of contact with extension personnel

\begin{tabular}{|l|c|c|c|}
\multicolumn{1}{|c|}{ Extension personnel } & $\begin{array}{c}\text { Regularly } \\
\text { F (\%) }\end{array}$ & $\begin{array}{c}\text { Occasionally } \\
\text { F (\%) }\end{array}$ & $\begin{array}{c}\text { Never } \\
\text { F (\%) }\end{array}$ \\
\hline VLEW(61.67\%) & 34 & 74 & 12 \\
\hline Agriculture Extension & $(28.33)$ & $(61.67)$ & $(10.00)$ \\
Officer & $(25.00)$ & 75 & 15 \\
(AEO) & & $(62.50)$ & $(12.50)$ \\
\hline Extension officer & 33 & & 25 \\
\hline Farmers organizations & $(27.50)$ & $(51.67)$ & $(20.83)$ \\
\hline Community coordinator & 34 & 70 & 16 \\
(SHGs) & $(28.33)$ & $(58.33)$ & $(13.33)$ \\
\hline Anganwadi Worker & 82 & 30 & 8 \\
\hline University personnel & $(68.33)$ & $(25.00)$ & $(6.67)$ \\
\hline NGOs Personnel & 70 & 33 & 17 \\
& $(58.33)$ & $(27.50)$ & 82 \\
\hline Bank Personnel & 10 & 28 & $(68.33)$ \\
\hline Block personnel & $(8.33)$ & $(23.33)$ & 86 \\
(VAO \& VRO) & 14 & 20 & $(71.67)$ \\
\hline
\end{tabular}


Figure.1 Distribution of farm women by marital status

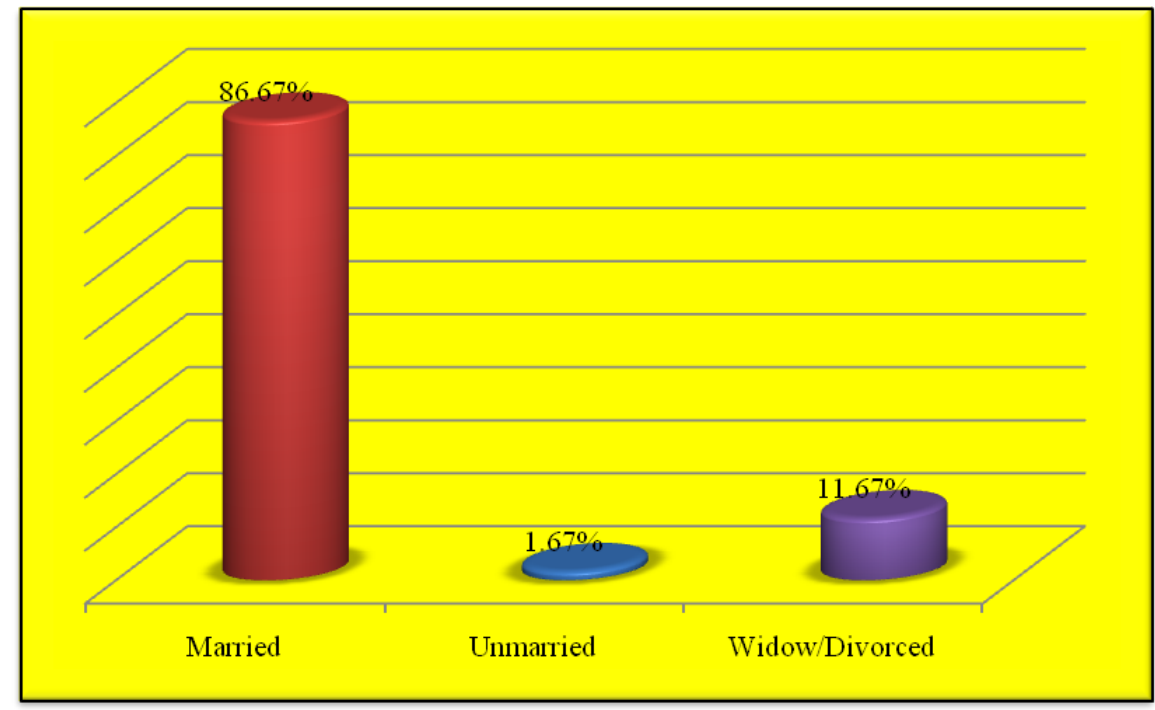

Figure.2 Distribution of farm women by family type

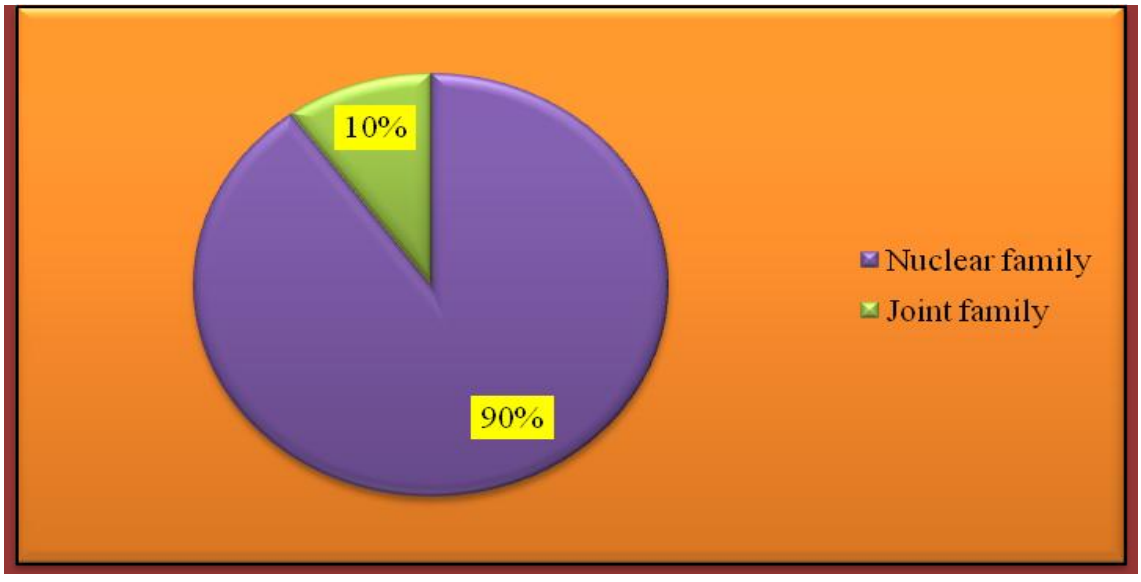

Figure.3 Distribution of farm women by cultivable land

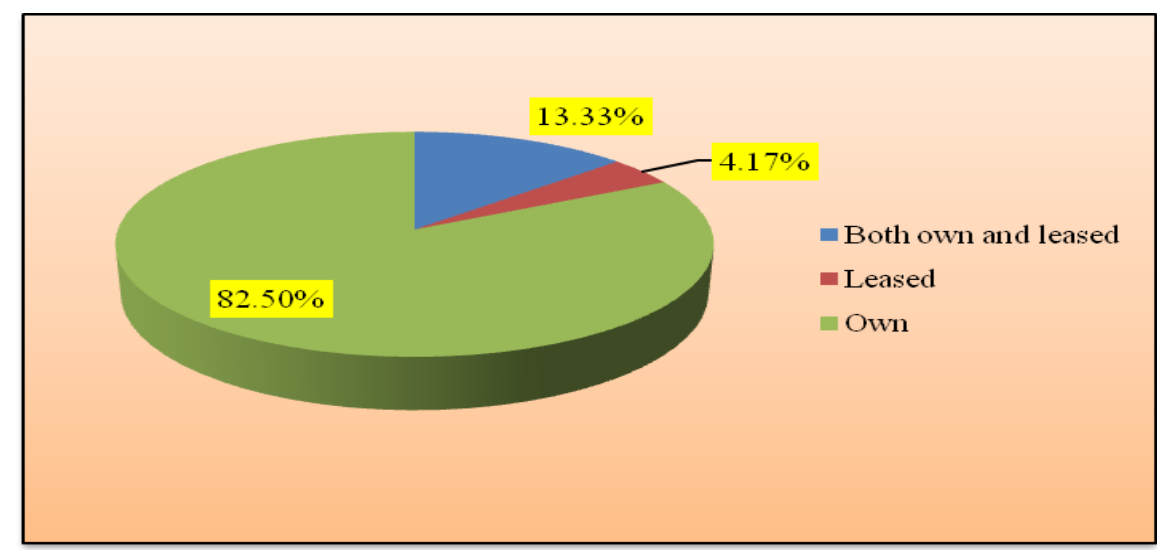


It is clear from the table 6,35 percent of the women farmers were holding medium level land size of farms followed by small $(30.83 \%)$ land holdings. Only 13 percent $(13.33 \%)$ of the farmers are with large land holding whereas land less farmers was only among small $(1.67 \%)$ of the farmers.

According to cultivable land among the farmers, it was observed that highest number $(99 \%)$ of farm women were having own lands while leased lands were found only among little amount of the farm women $(4.17 \%)$ (Fig. 3).

With reference to work experience, majority $(38.33 \%)$ of the farm women were having below 10 years of work experience and only five per cent of farm women were having above 30 years of work experience. Whereas 36.67 per cent of farm women were having 10-20 years of work experience whereas 20 per cent of farm women were having 20-30 years of work experience (Table 7).

Table 8 depicted that the main crops cultivated in the selected locale by the farm women. It disclosed that cotton was the major crop grown $(87.50 \%)$ by the farm women followed by cereals $(79.17 \%)$ such as paddy and maize. Vegetables (76.67\%) and flowers (66.67\%) were next following grown crops while pulses $(55.83 \%)$ were the less grown crops by farm women evidencing the shortage of irrigation waters in the region.

Table 9 indicated that cent percent of source of information about farming was received through traditional knowledge and family members followed by Neighbour's (95\%), television (81.66\%), agricultural extension officer $(60 \%)$, mobile phone $(45 \%)$, radio (29.17\%), newspaper (26.67\%), agricultural university (25\%) and Krishivigyankendras $(10 \%)$.
Table 10 indicates that the regularly participating farm women in different organizations. A little less than cent per cent $(81.67 \%)$ of the farm women were participated in self-help groups followed by anganwadi centre $(49.17 \%)$, gram panchayat (28.33\%), taluk panchayat (24.17\%), farmers organization $(21.67 \%)$, zilla panchayat $(20 \%)$ and mahila mandal $(9.17 \%)$.

With reference to frequency of farm women contacts with external personnel, majority of the farm women contacted with external personnel were community coordinator $(68.33 \%)$ and anganwadi worker (58.33\%) whereas occasionally contacted farm women were block personnel (66.67\%), agriculture extension officer (62.50\%), VLEW (61.67\%), Farmers organizations $(58.33 \%)$ and Extension officer (51.67\%) (Table 11).

From the study, it was concluded that majority of the farm women were married and belonged to young age group with high school education and with below 10 years of work experience. Majority of the farm women were having farming as their family occupation by holding medium level land size having their own lands and belonged to small families with less than three members in the family. It was observed that main crops cultivated in the selected locale by the farm women were cotton, cereals, vegetables and flowers. Less than cent per cent of the farm women were participating regularly in self-help groups by contacting community coordinator as their external personnel and received source of information about farming from traditional knowledge and family members.

\section{References}

1. Bansal, V and Joshi, V. 2018. Profile characteristics of far women knowledge groups. International Journal of Science, Environment and 
Technology. 7(5): 1532-1537.

2. Dayya, P and Bansal, V. 2016. Socio economic profile of NGOs trainees in Udaipur district. International Journal of Science, Environment and Technology. 5(6): 4219 - 4224. empowerment of rural women through self-help groups in Udaipur district. M.Sc. Thesis, MaharanaPratap University of Agriculture and Technology, Udaipur.

3. Kumawat, P. 2017. A study on

\section{How to cite this article:}

Sunitha, N., T. Sarah Kamala and Neela Rani, R. 2019. Profile Characteristics of Farm Women with Reference to Knowledge Groups in Maheshwarammandal of Rangareddy District, India. Int.J.Curr.Microbiol.App.Sci. 8(07): 1597-1605. doi: https://doi.org/10.20546/ijcmas.2019.807.190 